\title{
Altered calbindin mRNA expression and calcium regulating hormones in rat diabetic pregnancy
}

\author{
K Hamilton ${ }^{1}$, M Tein 1 , J Glazier ${ }^{1}$, E B Mawer², J L Berry², \\ R J Balment ${ }^{1}$, R D H Boyd ${ }^{3}$, H O Garland ${ }^{1 *}$ and C P Sibley ${ }^{1}$ \\ ${ }^{1}$ School of Biological Sciences, Academic Unit of Child Health, University of Manchester, Manchester M13 9PT, UK \\ ${ }^{2}$ Department of Medicine, University of Manchester, Manchester M13 9PT, UK \\ ${ }^{3}$ St George's Medical School, Cranmer Terrace, London SW17 ORE, UK \\ (Requests for offprints should be addressed to K Hamilton, Academic Unit of Child Health, University of Manchester, St Mary's Hospital, Hathersage Road, \\ Manchester M13 OJH, UK; Email: Khamil@fs1.cmht.nwest.nhs.uk.) \\ ${ }^{*}($ Dr H O Garland has since deceased)
}

\begin{abstract}
Offspring of rats with diabetes mellitus are at risk of reduced calcium and bone mineral content. Altered expression of the maternal calcium binding proteins, calbindin- $\mathrm{D}_{9 \mathrm{~K}}$ and calbindin- $\mathrm{D}_{28 \mathrm{~K}}$, which are involved in renal and placental calcium transport, may underlie these problems. We have investigated the effect of diabetes on circulating concentrations of regulatory hormones with respect to calbindin-D mRNA concentrations. Three rat groups were studied; control (CP), streptozotocininduced diabetic (DP), and insulin-treated diabetic (DPI) pregnant rats. Calbindin- $\mathrm{D}_{9 \mathrm{~K}}$ and calbindin- $\mathrm{D}_{28 \mathrm{~K}} \mathrm{mRNA}$ abundance in placenta and maternal kidney were measured at days 7, 15, 18 and 21 of gestation, together with serum or plasma concentrations of 1,25 dihydroxyvitamin $\mathrm{D}_{3}\left(1,25(\mathrm{OH})_{2} \mathrm{D}_{3}\right)$, parathyroid hormone $(\mathrm{PTH})$, $\mathrm{PTH}-$ related protein $(\mathrm{PTHrP})$, calcitonin, oestradiol and IGF-I. An increase in placental calbindin- $\mathrm{D}_{9 \mathrm{~K}} \mathrm{mRNA}$ abundance between days 18 and 21 in CP and DPI rats was severely blunted in the DP rats. In contrast, renal
\end{abstract}

calbindin- $\mathrm{D}_{28 \mathrm{~K}} \mathrm{mRNA}$ abundance was greater at days 7 , 15 and 18 in DP compared with $\mathrm{CP}$ rats, as was calbindin- $\mathrm{D}_{9 \mathrm{~K}}$ at day 18. Calcitonin concentrations showed no differences between the groups, and both PTH and IGF-I were reduced over the first half of gestation, unlike the calbindins. In contrast, the concentrations of PTHrP and $1,25(\mathrm{OH})_{2} \mathrm{D}_{3}$ were reduced at term in the DP group compared with the other two groups. Plasma oestradiol concentrations were lower in DP than in CP rats at days 7, 15 and 18, and most striking was the absence in DP rats of the peak of oestradiol seen at day 18 in CP rats. Despite the similarity between changes in placental calbindin mRNA and $1,25(\mathrm{OH})_{2} \mathrm{D}_{3}$, previous work has shown placental calbindin- $\mathrm{D}_{9 \mathrm{~K}}$ regulation to be vitaminD-independent. These studies produce suggestive evidence, therefore, that PTHrP and oestradiol may be involved in the altered calbindin-D expression by kidney and placenta in rat diabetic pregnancy.

Journal of Endocrinology (2000) 164, 67-76

\section{Introduction}

Significant alterations in calcium homeostasis occur in up to $50 \%$ of infants born to insulin-dependent diabetic mothers (Tsang et al. 1972). Such children have an increased incidence of hypocalcaemia (Tsang et al. 1972, Mimouni et al. 1986, 1990) and either a decreased (Lapillone et al. 1997) or an increased (Mimouni et al. 1988) bone mineral content compared with normal infants. A reduced bone mineral content, retarded skeletal development, or both, is found in the offspring of genetically diabetic rats (Verhaeghe et al. 1988a) and those rendered diabetic by streptozotocin (STZ; Uriu-Hare et al. 1985, Demignon \& Bonneton-Rebut 1988). The reduced bone mineral content in the rat may be attributable in part to a reduced maternofetal placental calcium flux (Husain et al. 1994), associated with an exacerbated maternal renal loss of calcium (Birdsey et al. 1995).

Both placental and renal epithelia transport calcium by an energy-dependent transcellular process (Shareghi \& Stoner 1978, Stulc \& Štulcová 1986). In pregnancy, the expression of the cytosolic calcium binding protein, calbindin- $\mathrm{D}_{9 \mathrm{~K}}$, appears to be rate-limiting to transcellular calcium transport across the rat placenta (Glazier et al. 1992). In diabetic rat pregnancy, the abundance of placental calbindin- $\mathrm{D}_{9 \mathrm{~K}} \mathrm{mRNA}$ is markedly reduced near term, in association with a diminished maternofetal calcium flux (Husain et al. 1994). In the kidney, the energy-dependent component of calcium reabsorption occurs mainly in the distal tubule and involves another 
cytosolic transporting protein, calbindin- $\mathrm{D}_{28 \mathrm{~K}}$ (the main renal protein) in addition to calbindin- $\mathrm{D}_{9 \mathrm{~K}}$ (Thomasset et al. 1982). One study has reported that maternal renal concentrations of calbindin- $\mathrm{D}_{9 \mathrm{~K}}$ and calbindin- $\mathrm{D}_{28 \mathrm{~K}}$ proteins at term were comparable between control and genetically diabetic rats (Verhaeghe et al. 1988b). The regulation of expression of calbindins in these two calcium-transporting epithelia is distinct: whereas renal calbindin expression is dependent on serum vitamin $\mathrm{D}_{3}$ metabolite concentrations (Thomasset et al. 1982), placental calbindin- $\mathrm{D}_{9 \mathrm{~K}}$ expression is apparently not regulated by this hormone (Glazier et al. 1995).

Altered placental and renal calcium handling in rat diabetic pregnancy may, at least in part, reflect an altered production or function of calcium regulatory hormones. However, it is not known when, in the course of pregnancy, the effect of diabetes on placental and renal calbindin expression manifests itself, nor how this relates to pregnancy and to diabetes-dependent changes in circulating hormones. The aim of this study was to address these questions by measuring calbindin- $\mathrm{D}_{9 \mathrm{~K}}$ and calbindin$\mathrm{D}_{28 \mathrm{~K}} \mathrm{mRNA}$ expression in placenta and kidney over the course of pregnancy in control, diabetic, and insulintreated diabetic rats. In the same animals, we also measured maternal serum or plasma concentrations of hormones associated with calcium homeostasis $(1,25$ dihydroxyvitamin $\mathrm{D}_{3}\left(1,25(\mathrm{OH})_{2} \mathrm{D}_{3}\right)$, parathyroid hormone $(\mathrm{PTH})$, PTH-related protein $(\mathrm{PTHrP})$ and calcitonin), and those likely to change in diabetes (insulin-like growth factor-I (IGF-I)) or pregnancy (oestradiol). Most of these hormones have also been shown to be putative controllers of calbindin-D expression. It is well known that both renal calbindins are vitamin-D-dependent (Thomasset et al. 1982). Both the placental calbindin- $\mathrm{D}_{9 \mathrm{~K}}$ gene (Darwish et al. 1991) and the renal calbindin- $\mathrm{D}_{28 \mathrm{~K}}$ gene (Gill \& Christakos 1995) have been shown to have an oestrogen-responsive element. Although the geneexpression effects of both $\mathrm{PTH}$ and PTHrP are unknown, PTH has been shown to increase cytosolic concentration of renal calbindin- $\mathrm{D}_{28 \mathrm{~K}}$ in vivo (Hemmingsen et al. 1996), whereas PTHrP has been shown to increase renal calbindin- $\mathrm{D}_{28 \mathrm{~K}}$ in the rat by a direct effect, without mediation by $1,25(\mathrm{OH})_{2} \mathrm{D}_{3}$ or plasma calcium (Hemmingsen et al. 1996). We hypothesised that a temporal association between altered calbindin-D expression and an alteration in one or more of the hormones measured would provide clues to the mechanisms responsible for the altered calcium handling by placenta and kidney associated with diabetic pregnancy in the rat.

\section{Materials and Methods}

\section{Animals}

All work was performed in accordance with the UK Animals (Scientific Procedures) Act 1986.
Female Sprague-Dawley rats (Charles River Laboratories, Wilmington, Kent, UK) weighing approximately $210 \mathrm{~g}$ at the start of the experiment were used. Animals were housed in individual wire-bottomed cages and exposed to a $12 \mathrm{~h}$ light: $12 \mathrm{~h}$ darkness cycle in a temperature controlled room $\left(21-23^{\circ} \mathrm{C}\right)$. Animals had commercial rat chow (CRM, Labsure, Poole, Dorset, UK) and tap water available ad libitum throughout the study. Three animal groups were studied.

Diabetic pregnant rats (group DP) Female rats aged 8 weeks were rendered diabetic by an i.p. injection of $60 \mathrm{mg} / \mathrm{kg} \mathrm{STZ} \mathrm{(Sigma,} \mathrm{Poole,} \mathrm{Dorset,} \mathrm{UK).} \mathrm{This} \mathrm{was}$ freshly dissolved in ice-cold $0 \cdot 1 \mathrm{M}$ citrate buffer ( $\mathrm{pH} 4 \cdot 8$ ) as detailed previously (Birdsey et al. 1995). Diabetes mellitus was confirmed 2 days later by the development of glycosuria (Labstix, Ames, Slough, Berks, UK) and hyperglycaemia (blood glucose concentration $>15 \mathrm{mM}$ ). Blood for the latter measurement was obtained by needle puncture of a tail vein and assayed using a blood glucose analyser (HemoCue Ltd, Sheffield, Yorks, UK). Any rat with a blood glucose concentration $<15 \mathrm{mM}$ was excluded from the study at this stage. Three days later, each female diabetic rat was housed with a nondiabetic male rat for mating. The day on which a vaginal copulation plug was found was designated day 1 of gestation (term $=22-23$ days).

Control pregnant rats (group CP) Control female animals received an i.p. injection of citrate buffer alone and were subsequently mated as described above.

\section{Insulin-treated diabetic pregnant rats (group DPI)} These rats were rendered diabetic as described above. Immediately after confirmation of diabetes, each animal received one interscapular s.c. 10\% porcine insulin implant (LinShin Canada Inc., Toronto, Canada) under halothane anaesthesia, in order to maintain a blood glucose concentration less than $10 \mathrm{mM}$. Insulin-treated rats were then allowed to mate as above. Maternal tail-vein blood glucose concentrations were monitored at 2-day intervals throughout gestation (HemoCue Ltd) and further insulin implants were given as appropriate to control glycaemia; each implant lasted approximately 10 days. As a control measure, some of the DP and CP group rats (see above) were given placebo implants. These had no effect on their blood glucose concentrations or any other variables. Data from DP and CP group animals with and without placebo implants were therefore pooled.

\section{Blood and tissue collection}

Animals were killed by cervical dislocation at day 7, 15, 18 or 21 of gestation. After immediate laparotomy, the terminal blood sample was withdrawn from the abdominal aorta and an aliquot immediately placed in a heparinised 
tube for plasma separation. Other blood aliquots were handled appropriately for specific hormone analysis (see below). Both kidneys and all placentas were removed, briefly blotted and immediately frozen in liquid nitrogen. All tissues were stored at $-80^{\circ} \mathrm{C}$.

Plasma was assayed for glucose concentration by the glucose oxidase-peroxidase method (Ames Sera-Pak, Bayer Diagnostics, Basingstoke, Hampshire, UK). Incubated samples were measured on a spectrophotometer (Shimadzu UV2101PC, Shimadzu Corp., Kyoto, Japan) at a wavelength of $505 \mathrm{~nm}$.

\section{RNA extraction and Northern/dot blot analysis}

Tissue was used from six to eight rats randomly chosen from each experimental group at each gestational sample time (except for day 7, when the chorioallantoic placenta is not fully formed). Total RNA was extracted from placentas (ten on day 15, four or five on day 18, and three on day 21 from each rat, again using random sampling) and one kidney (left or right, alternate sampling), as described previously (Glazier et al. 1992). The resulting RNA pellet was dissolved in RNase-free water, quantified by measuring absorbance at $260 \mathrm{~nm}$ and then stored at $-80{ }^{\circ} \mathrm{C}$.

Sets of dot blots of all placental and all kidney RNA were prepared using $20 \mathrm{mg}$ total RNA from each tissue sample, incubated with $10 \times$ standard saline citrate (SSC) and $50 \%$ formamide at $60{ }^{\circ} \mathrm{C}$ for $10 \mathrm{~min}$. The sample was applied to a filter (Hybond N, Amersham International, Bucks, UK), washed twice with $10 \times$ SSC and fixed by exposure to u.v. light.

We have previously shown that the calbindin- $\mathrm{D}_{9 \mathrm{~K}}$ cDNA used here detected a single transcript of the expected size $(0.6 \mathrm{~kb})$ on Northern blots of placental mRNA (Glazier et al. 1992, 1995). To check the size of the renal calbindin- $\mathrm{D}_{9 \mathrm{~K}}$ and calbindin- $\mathrm{D}_{28 \mathrm{~K}}$ transcripts, a pool of poly-A enriched RNA (Pharmacia Biotech, St Albans, UK) was prepared from kidneys of the CP and DP groups at each gestational age and Northern blots prepared as described previously (Glazier et al. 1992).

Filters were prehybridised, then hybridised with ${ }^{32} \mathrm{P}-$ labelled cDNA for either rat intestinal calbindin- $\mathrm{D}_{9 \mathrm{~K}}$ (placenta and kidney) or calbindin- $\mathrm{D}_{28 \mathrm{~K}}$ (kidney only) as described previously (Thomasset et al. 1982, Lomri et al. 1989), with the addition, at the end of the previous method, of two stringency washes $(0.1 \times$ SSC, $0 \cdot 1 \%$ SDS at $60{ }^{\circ} \mathrm{C}$ for $20 \mathrm{~min}$ ) for calbindin- $\mathrm{D}_{28 \mathrm{~K}}$ hybridisations.

Replicates of all dot blots were probed with oligo-dT as a control to correct for variations in loading between samples. All blots were analysed and dot blots quantified on an autoimager (Packard Instant Imager, Packard Bioscience, Berks, UK) for varying times, depending on the strength of the signal ( $2 \mathrm{~min}$ for oligo-dT, up to 3 days for the calbindin- $\mathrm{D}_{9 \mathrm{~K}}$ Northern blot). The Instant Imager provides a visual image of the signal and quantitates it by measuring radioactive emission with a wide dynamic range. Northern blots were also autoradiographed at $-80{ }^{\circ} \mathrm{C}$.

\section{Measurements on terminal blood samples}

$\mathbf{1 , 2 5}(\mathrm{OH})_{2} \mathrm{D}_{3} \quad \mathrm{~A} 1 \mathrm{ml}$ aliquot of blood was placed in a lithium-coated tube and the plasma separated by centrifugation. Plasma $1,25(\mathrm{OH})_{2} \mathrm{D}_{3}$ concentration was measured using a kit (IDS Ltd, Boldon, Tyne and Wear, UK), which involved immunoextraction followed by radioimmunoassay as described previously (Fraser et al. 1997). The inter- and intra-assay variations were $8 \%$ and $10 \%$ respectively, and the assay sensitivity was $5 \mathrm{pM}$.

PTH To obtain serum, $1 \mathrm{ml}$ blood was allowed to clot and then centrifuged. PTH concentration was determined in duplicate using a Rat PTH Immunoradiometric Assay kit (Nichols Diagnostics, Cambridge, UK). Intra-assay variation was $4-4 \cdot 3 \%$, inter-assay variation $4 \cdot 3-4 \cdot 7 \%$ and assay sensitivity was $1 \mathrm{pg} / \mathrm{ml}$ (data provided by the suppliers).

PTHrP One millilitre of blood was dispensed into an ice-cold PTHrP cocktail tube (Nichols Diagnostics). The sample was centrifuged and the plasma used for determination of PTHrP (in duplicate) using the Allegro PTHrP Immunoradiometric Assay (Nichols Diagnostics). The supplier reported that this assay had a sensitivity of $0.3 \mathrm{pM}$, an intra-assay variation of $2 \cdot 9-9 \cdot 5 \%$ and an inter-assay variation of $5 \cdot 3-5 \cdot 6 \%$. The validity of using this kit for rat measurements has been confirmed (Benitez-Verguizas \& Esbrit 1994, Naranjo et al. 1994).

Calcitonin Calcitonin concentration was determined in duplicate serum samples using a Calcitonin Chemiluminescence Immunoassay kit (Nichols Diagnostics). Intra-assay variation was $6 \cdot 7-8 \cdot 3 \%$, inter-assay variation was $6 \cdot 6-11 \cdot 6 \%$, and assay sensitivity was $3-5 \mathrm{pg} / \mathrm{ml}$ as reported by the suppliers. The validity of using this kit for rat measurements has been confirmed (Kalu et al. 1988).

Oestradiol Oestradiol concentration in duplicate $100 \mu \mathrm{l}$ serum samples was determined using a Coat-A Count Oestradiol radioimmunoassay kit (DPC Limited, Gwynedd, UK). Intra-assay variation was $4-7 \%$, interassay variation $4 \cdot 2-8 \cdot 1 \%$ and assay sensitivity $8 \mathrm{pg} / \mathrm{ml}$ as reported by the suppliers.

IGF-I IGF-I was measured in duplicate $200 \mu \mathrm{l}$ serum samples using an IGF-I Immunoassay kit (Nichols Diagnostics). Assay sensitivity was $0 \cdot 1 \mathrm{ng} / \mathrm{ml}$ as reported by the suppliers. Intra-assay variability was $2 \cdot 4-3 \%$, the inter-assay coefficient of variation was $5 \cdot 2-8 \cdot 4 \%$. 


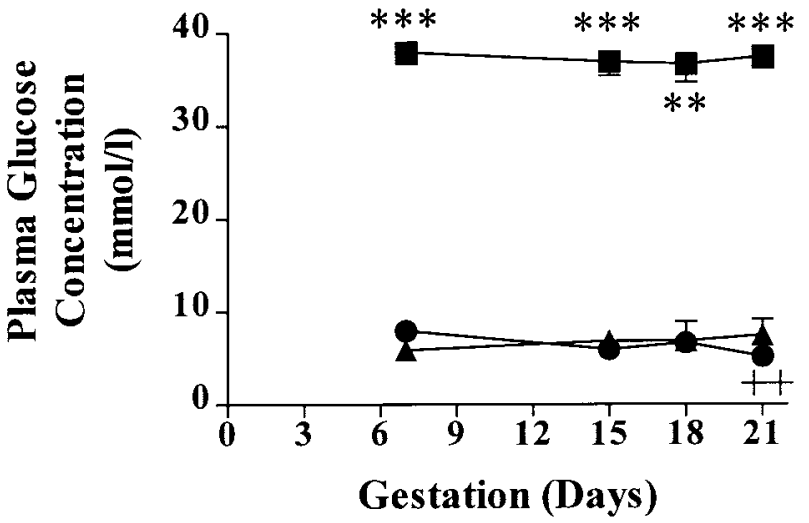

Figure 1 Plasma glucose concentrations from the terminal sample taken at days $7,15,18$ and 21 of gestation in CP $(\bullet, n=15,9,9$, 8), DP $(\boldsymbol{\square}, n=14,9,8,14)$ and DPI $(\boldsymbol{\Lambda}, n=11,9,7,9)$ rats. ${ }^{* *} P<0 \cdot 01$, ${ }^{* *} P<0 \cdot 001$ compared with $\mathrm{CP}$ and $\mathrm{DPl} ;++P<0 \cdot 01$ compared with DPI (Mann-Whitney U-tests). Values are means \pm S.E.M.

\section{Statistics}

All data are presented as means \pm S.E.M, and $n=$ number of animals. A two-way analysis of variance (ANOVA) was first performed, including the Bartlett-Box test for the homogeneity of variances between the groups. If variances were not significantly different, a one-way ANOVA with Scheffe's post hoc test was performed at each gestational time point, to distinguish differences between the three groups. If variances were significantly different, the nonparametric Kruskall-Wallis test was used, followed by paired Mann-Whitney $U$-tests for specific differences between the groups. Any further specific post hoc tests (a decrease or increase in values) were performed using an unpaired Student's $t$-test.

\section{Results}

\section{Plasma glucose}

Plasma glucose concentrations in terminal blood samples for the DP group were significantly greater than those in the CP and DPI groups at each gestational time point (Fig. 1). Plasma glucose concentrations in the DPI rats were comparable to those in the CP group, except at day 7 , when DPI values were slightly but significantly $(P<0 \cdot 01)$ lower.

\section{Gestational changes in placental and renal calbindins}

We have previously shown, by Northern blotting, that probing of placental mRNA with the calbindin- $\mathrm{D}_{9 \mathrm{~K}}$ cDNA gives a single transcript of $0.6 \mathrm{~kb}$, as expected (Glazier et al. 1992, 1995, Husain et al. 1994). Figure $2 a$ shows data from placental dot blots probed with calbindin$\mathrm{D}_{9 \mathrm{~K}} \mathrm{cDNA}$, normalised to oligo-dT concentrations. In CP animals, a large and significant $(P<0 \cdot 01, t$-test between $\mathrm{CP}$ day 18 and CP day 21) increase in the abundance of calbindin- $\mathrm{D}_{9 \mathrm{~K}}$ mRNA was apparent over the last 3 days of gestation. This increase was severely attenuated by day 21 in the DP group $(P<0 \cdot 001$ comparing $\mathrm{CP}$ and DP animals). The insulin-treated group showed a pattern similar to that of the CP group, with a sharp increase in calbindin- $\mathrm{D}_{9 \mathrm{~K}}$ mRNA between days 18 and 21, to values intermediate between those in the other two groups - that is, DPI calbindin- $\mathrm{D}_{9 \mathrm{~K}} \mathrm{mRNA}$ expression was significantly lower than in CP and higher than in DP groups at day 21. Some fluctuations earlier in gestation meant that calbindin- $\mathrm{D}_{9 \mathrm{~K}} \mathrm{mRNA}$ in the insulin-treated group was lower than that in the CP group at days 15 and 18, and lower than that in the DP group at day 15. However, the major change in calbindin- $\mathrm{D}_{9 \mathrm{~K}} \mathrm{mRNA}$ expression from day 18 to day 21 was comparable between the CP and DPI groups (3.7-fold and 5.7-fold respectively), but was lower (only $2 \cdot 4$-fold) in the DP group.

Northern hybridisation of renal poly-A-enriched RNA (from $\mathrm{CP}$ and $\mathrm{DP}$ rats) with calbindin- $\mathrm{D}_{9 \mathrm{~K}} \mathrm{cDNA}$ revealed a single transcript at $0.6 \mathrm{~kb}$ in both the $\mathrm{CP}$ and DP groups (Fig. 3a), consistent with previous observations (Huang et al. 1989, Li \& Christakos 1991). Quantitation of renal calbindin- $\mathrm{D}_{9 \mathrm{~K}} \mathrm{mRNA}$ in dot blots, normalised to oligo-dT, is shown in Fig. $2 b$. In CP animals, calbindin$D_{9 K}$ mRNA levels remained steady until day 18 of gestation, after which there was a sharp increase $(P<0 \cdot 02$, comparing days 18 and 21 by $t$-test). In contrast to the pattern seen in the placenta, renal calbindin- $\mathrm{D}_{9 \mathrm{~K}} \mathrm{mRNA}$ in diabetic animals was higher than in either the $\mathrm{CP}$ or DPI groups throughout gestation. However, this achieved statistical significance only at day $18(P<0.001 \mathrm{DP}$ compared with CP; $P<0 \cdot 01 \mathrm{DP}$ compared with DPI, one-way ANOVA). At term, no differences existed between the three groups. This was due primarily to the increase in calbindin- $\mathrm{D}_{9 \mathrm{~K}} \mathrm{mRNA}$ in the $\mathrm{CP}$ group, rather than a decrease in the values in DP animals.

Northern hybridisation of rat renal poly-A RNA with calbindin- $\mathrm{D}_{28 \mathrm{~K}}$ cDNA (Fig. 36 ) revealed three transcripts, at $3 \cdot 3,2 \cdot 8$ and $1.9 \mathrm{~kb}$, which agrees well with previous reports (Huang \& Christakos 1988, Huang et al. 1989). All three transcripts on the Northern blot appeared to change similarly over gestation and to have greater expression in the DP group than in the CP group. This was confirmed when quantification of the dot blot was performed (Fig. 2c). In CP kidneys, there was a trend in calbindin$\mathrm{D}_{28 \mathrm{~K}}$ mRNA expression similar to that seen for calbindin$\mathrm{D}_{9 \mathrm{~K}}$, with mRNA levels remaining relatively low until day 18, after which a sharp increase occurred to day 21 $(P<0 \cdot 05$, comparing days 18 and 21 by $t$-test). Again, calbindin- $\mathrm{D}_{28 \mathrm{~K}} \mathrm{mRNA}$ levels in DP kidneys were greater $(P<0 \cdot 01$, Mann-Whitney U-test) than in those of the CP animals throughout gestation until day 21. As for 
(a)

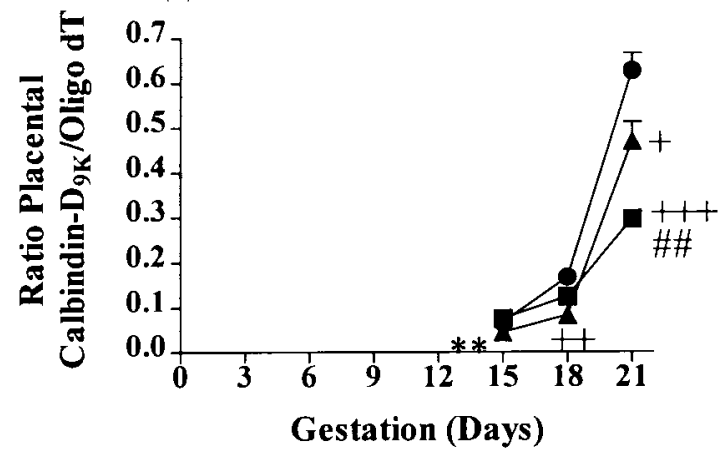

(b)

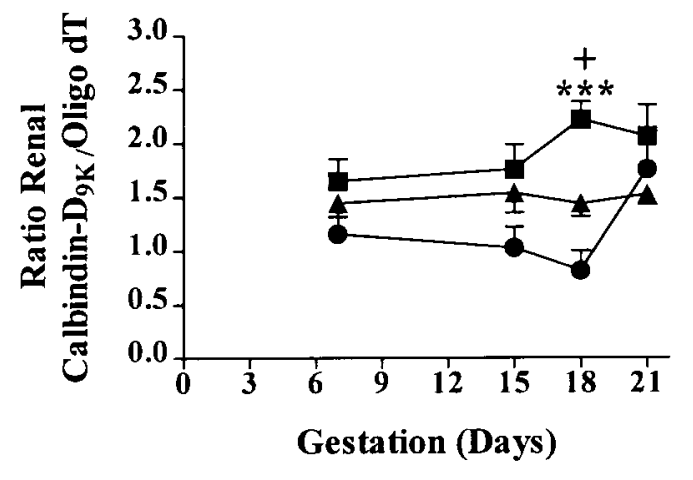

(c)

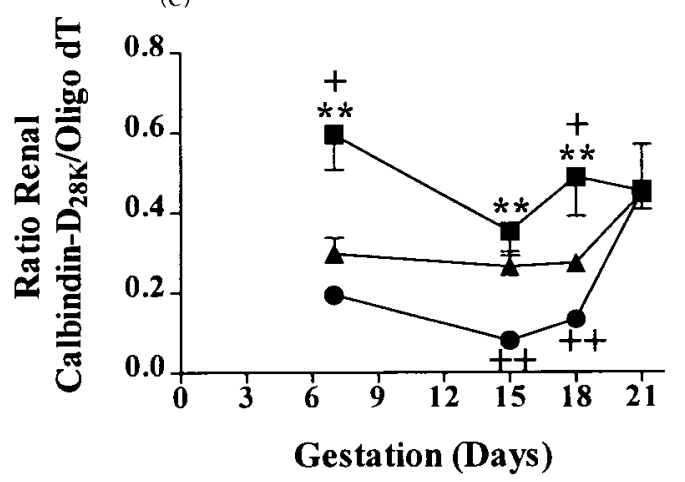

Figure 2 (a) Ratio of placental calbindin- $D_{9 k} m R N A$ to oligo-dT at days 15,18 and 21 of gestation in $\mathrm{CP}(\bullet, n=8,8,8)$, DP ( $n=8,8,8)$ and DPI $(\boldsymbol{\Delta}, n=8,7,8)$ rats. ${ }^{* *} P<0.01$ compared with $\mathrm{CP}$ and $\mathrm{DP} ;+P<0 \cdot 05,++P<0 \cdot 01,+++P<0 \cdot 001$ compared with $C P$; \#\#P<0.01 compared with DPI (Mann-Whitney U-tests). Values are means \pm S.E.M. (b) Ratio of renal calbindin- $D_{9 K}$ mRNA to oligo-dT at days $7,15,18$ and 21 of gestation in $\mathrm{CP}(\boldsymbol{\bullet}, n=6,6$, $6,6), \mathrm{DP}(\boldsymbol{\square}, n=6,6,6,6)$ and DPI $(\boldsymbol{\Lambda}, n=6,6,6,6)$ rats. ${ }^{* * *} P<0 \cdot 001$ compared with $C P ;+P<0 \cdot 05$ compared with DPI (one-way ANOVA plus Scheffé's test). Values are means \pm S.E.M. (c) Ratio of renal calbindin- $\mathrm{D}_{28 \mathrm{~K}} \mathrm{mRNA}$ to oligo-dT at days 7,15 , 18 and 21 of gestation in CP $(\bullet, n=6,6,6,6), \mathrm{DP}(\boldsymbol{\square}, n=6,6,6$, 6) and DPI $(\boldsymbol{\Lambda}, n=6,6,6,6)$ rats. ${ }^{* *} P<0 \cdot 01$ compared with $C P$; $+P<0 \cdot 05,++P<0 \cdot 01$ compared with DPI (Mann-Whitney U-tests). Values are means \pm S.E.M. calbindin- $\mathrm{D}_{9 \mathrm{~K}}$, the DPI kidneys were intermediate between the other two groups, and showed a gestational pattern in mRNA expression similar to that seen in the CP group.

Gestational changes in maternal hormone concentrations

$1,25(\mathrm{OH})_{2} \mathrm{D}_{3}$ (Fig. 4a) Maternal plasma concentrations of $1,25(\mathrm{OH})_{2} \mathrm{D}_{3}$ remained relatively stable in both the $\mathrm{CP}$ and DPI groups until day 18 of gestation, when there was a marked, significant increase $(P<0 \cdot 01$ for both groups, Mann-Whitney $U$-test). In the diabetic animals the concentration of $1,25(\mathrm{OH})_{2} \mathrm{D}_{3}$ was significantly $(P<0 \cdot 05)$ lower than that in the CP and DPI animals at day 15, and failed to show the increase seen in the other two groups towards term.

PTH (Fig. 4b) Maternal serum PTH concentrations differed between the three groups early in gestation. In particular, values for the DP group were significantly $(P<0 \cdot 001)$ lower than the CP group at day 7 . Toward the end of gestation (days 18 and 21), no significant differences were apparent between the groups, and there was a consistent increase over the last 3 days of gestation in all groups.

PTHrP (Fig. 4c) DP animals showed a steady decrease in PTHrP concentrations from day 7 of pregnancy and, as a result, both the CP and DPI groups had significantly greater serum PTHrP concentrations than the DP animals at days 18 and 21 of gestation. This contrasts with the data for PTH, for which no significant differences were seen between groups at these stages. The value in the DPI group was significantly greater than those in the other two groups at day 15.

Calcitonin There was a decrease in calcitonin concentrations in each group as gestation proceeded, but no statistically significant differences were apparent between the three rat groups at any stage of gestation (data not shown).

Oestradiol (Fig. 4d) Maternal serum oestradiol concentrations in CP animals were greatest at day 18 of gestation, with a sharp decrease towards term. In contrast, in the DP group oestradiol concentrations decreased steadily throughout gestation and were lower than in controls until term, although this achieved significance only at day 18 $(P<0 \cdot 01 \mathrm{CP}$ compared with DP, Mann-Whitney $U$-test $)$. In the DPI rats, oestradiol concentrations were also greater than in the DP group until day 18 , when values decreased sharply, to become lower than in either of the other groups. It is striking that both the DP and DPI groups failed to show the late gestational peak in oestradiol concentration that was evident at day 18 in $\mathrm{CP}$ rats. 


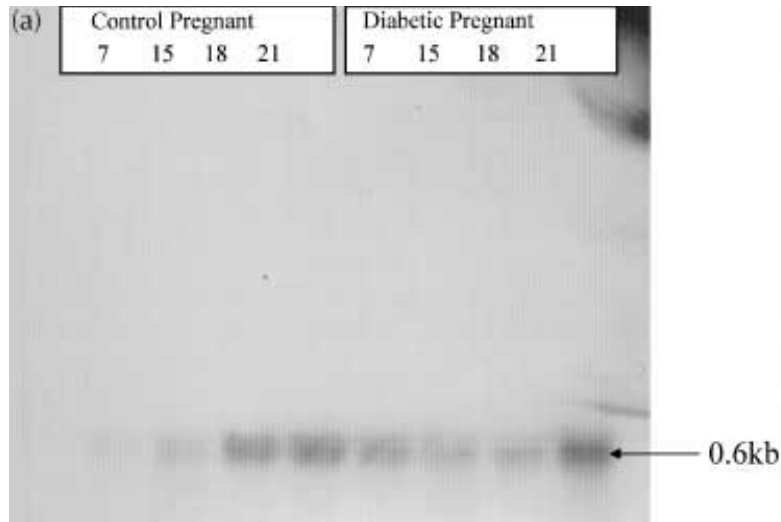

(b)
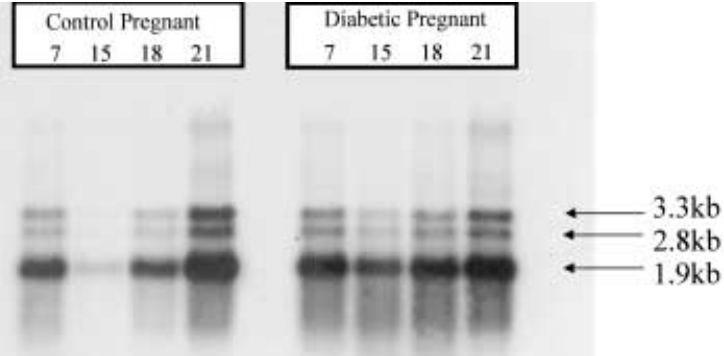

Figure 3 (a) Northern hybridisation of rat renal mRNA from CP and DP groups at days 7, 15, 18 and 21 of gestation, probed with ${ }^{32}$ P-labelled cDNA for calbindin- $\mathrm{D}_{9 \mathrm{~K}}$. Equal amounts $(12 \mu \mathrm{g})$ of poly-A-enriched mRNA were loaded in each lane. RNA was pooled before poly-A extraction from six rats at each gestational time point. The arrow indicates a transcript at 0.6 kb. (b) Northern hybridisation of rat renal mRNA from CP and DP groups at days 7, 15, 18 and 21 of gestation, probed with ${ }^{32} \mathrm{P}$-labelled cDNA for calbindin- $\mathrm{D}_{28 \mathrm{~K}}$. Equal amounts $(10 \mu \mathrm{g})$ of poly-A-enriched mRNA were loaded in each lane. RNA was pooled before poly-A extraction from six rats at each gestational time point. The arrows indicate transcripts at 3.3, $2 \cdot 8$ and $1 \cdot 9 \mathrm{~Kb}$.

IGF-I (Fig. 4e) Maternal serum IGF-I concentrations showed a marked gestational decrease in all groups. The DP animals had a greatly reduced serum IGF-I concentration compared with both CP and DPI rats early in pregnancy $(P<0 \cdot 001$ at days 7 and 15, Mann-Whitney U-test). Towards term, hormone concentrations in the three groups of animals began to converge, and by day 21 there was no significant difference between the groups.

\section{Discussion}

Gestational changes in placental and renal calbindins

Over the last third of normal pregnancy, the rat fetus accumulates more than $99 \%$ of its body calcium (Comar 1956). During this time, the unidirectional maternofetal placental calcium transfer increases markedly and approaches net flux (Glazier et al. 1992, Štulc \& Štulcová 1986). This is normally matched by a gestational increase in placental calbindin- $\mathrm{D}_{9 \mathrm{~K}}$ mRNA expression (current data and Glazier et al. 1992, Krisinger et al. 1992), suggesting that this protein is rate-limiting to placental calcium transport in the rat. Here, we report a progressively blunted gestational increase in placental calbindin$\mathrm{D}_{9 \mathrm{~K}}$ mRNA expression in the diabetic pregnant rat, complementing previous data showing a reduction at term (Husain et al. 1994, Verhaeghe et al. 1988b). The diminished increase in placental calbindin- $\mathrm{D}_{9 \mathrm{~K}}$ mRNA expression in diabetic animals that we observed from day 18 of pregnancy correlates with the diminished maternofetal placental calcium flux and lower fetal calcium content previously observed in these animals (Husain et al. 1994).
In normal pregnancy, the increased fetal requirement for calcium as gestation proceeds places an increasing demand on maternal calcium homeostasis, although maternal plasma calcium concentrations are maintained in the rat towards term (Green \& Hatton 1988, Husain et al. 1994) and bone calcium stores are not depleted (Miller et al. 1986). One possible mechanism whereby the non-diabetic mother might increase dietary calcium availability for the fetus is to limit renal losses by increasing renal calcium reabsorption. Indeed, previous reports from our laboratory have shown that there is a slight decrease in maternal renal calcium excretion towards the end of pregnancy (Birdsey et al. 1995, Garland et al. 1997). This may result, at least partially, from the sharp increase we have observed here in the expression of both calbindin-D species in the maternal kidney over days 18-21 of gestation. Such an increase would serve to enhance maternal renal calcium reabsorption in the distal tubule, thereby making more calcium available to the mother.

The novel longitudinal design of our study showed that renal calbindin-D mRNA expression was greatly increased in diabetic pregnant rats, compared with control values, up to day 18 of gestation. Our findings, at term, that maternal renal abundance of calbindin- $\mathrm{D}_{9 \mathrm{~K}}$ and calbindin- $\mathrm{D}_{28 \mathrm{~K}}$ mRNA were comparable between control and diabetic rats agree well with previous observations (Verhaeghe et al. 1988b). The fact that renal calbindin mRNA abundance is high at the start of diabetic pregnancy may be interpreted as an adaptive response to the extremely high renal calcium output that occurs immediately after the onset of experimental diabetes (Anwana 1989, Birdsey et al. 1995). It is, perhaps, surprising that this is not further enhanced as the increased calcium demands 
(a)

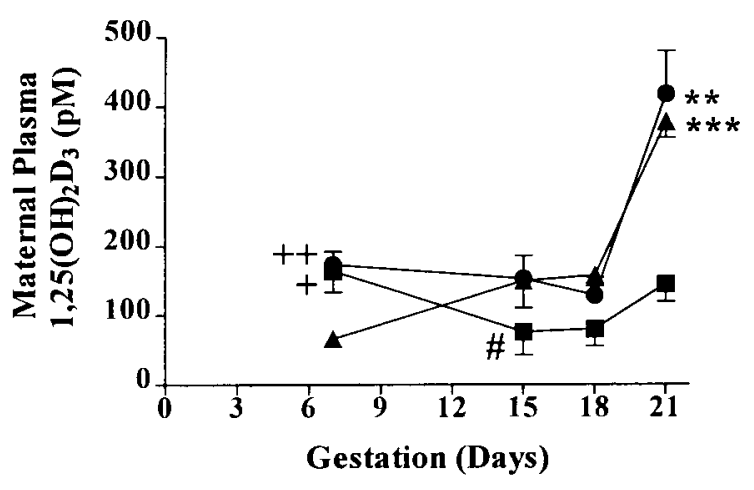

(b)

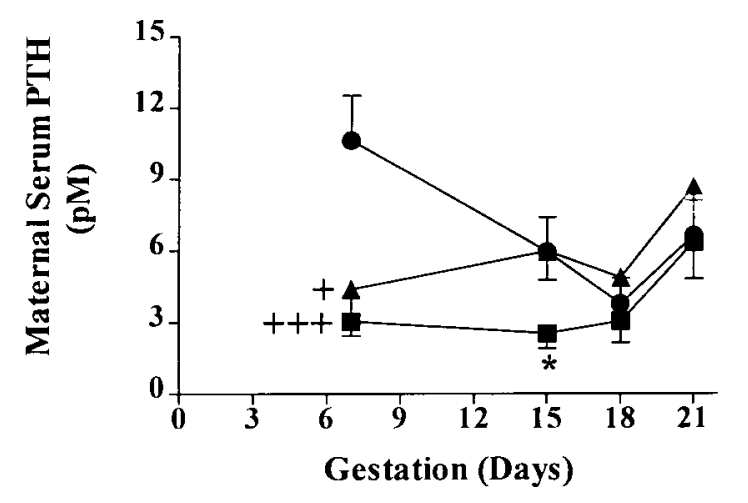

(c)

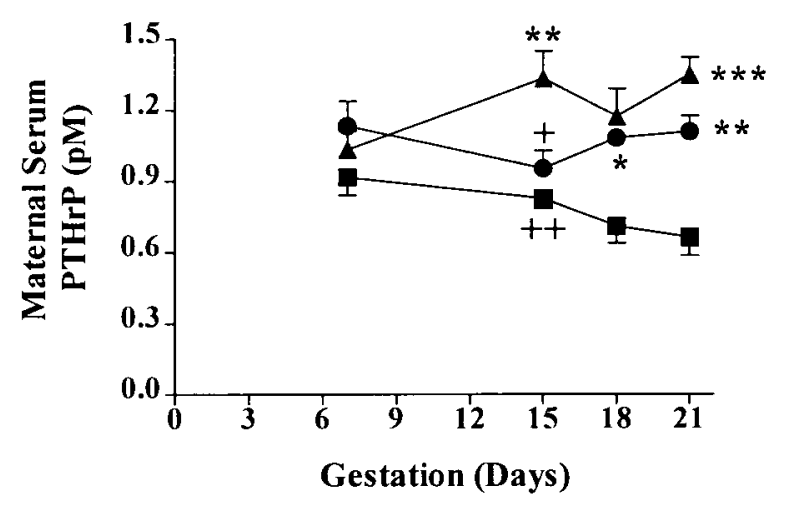

(d)

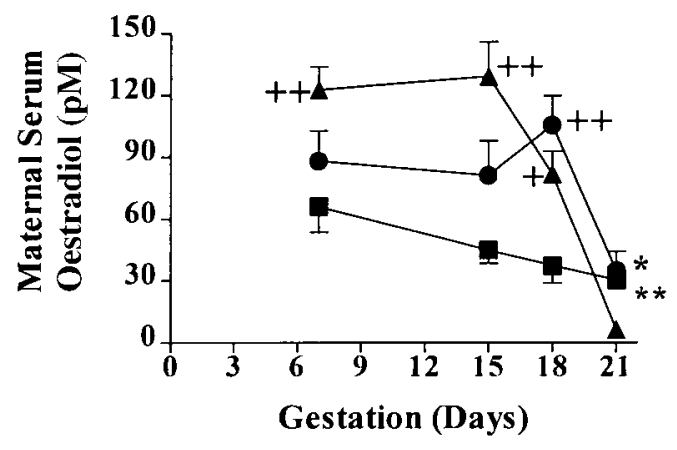

(e)

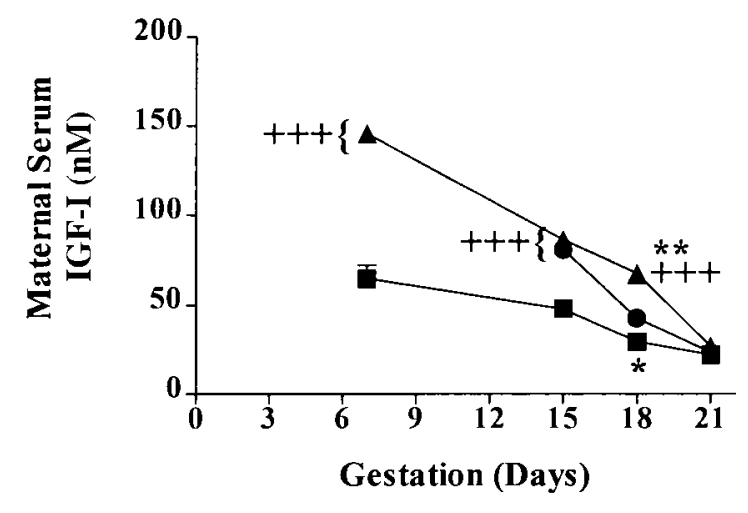

Figure 4 (a) Maternal plasma 1,25(OH) $\mathrm{D}_{3}$ at days 7, 15, 18 and 21 of gestation in $\mathrm{CP}(\boldsymbol{\bullet}, n=12,7,7,9), \mathrm{DP}(\boldsymbol{\square}, n=11,9,10,10)$ and $\mathrm{DPI}(\boldsymbol{\Lambda}, n=8,8,8,8)$ rats. $+P<0 \cdot 05,++P<0.01$ compared with DPI; $\# P<0 \cdot 05$ compared with $\mathrm{CP}$ and DPI; ${ }^{* \star} P<0 \cdot 01,{ }^{*} * * P<0 \cdot 001$ compared with DP (Mann-Whitney U-tests). Values are means \pm S.E.M. (b) Maternal serum PTH at days $7,15,18$ and 21 of gestation in CP $(\bullet, n=9,10,9,9), \mathrm{DP}(\boldsymbol{\square}, n=10,10,12,12)$ and $\mathrm{DPI}(\boldsymbol{\Delta}, n=7,8,7,8)$ rats. $+P<0 \cdot 05,+++P<0 \cdot 001$ compared with $\mathrm{CP} ;{ }^{*} P<0 \cdot 05$ compared with CP and DPI (Mann-Whitney U-tests). Values are means \pm S.E.M. (c) Maternal serum PTHrP at days $7,15,18$ and 21 of gestation in CP $(\bullet, n=8,7,6,7)$, DP $(\boldsymbol{\bullet}, n=9,11,9,10)$ and DPI $(\boldsymbol{\Lambda}, n=10,8,7,8)$ rats. $+P<0 \cdot 05,++P<0 \cdot 01$ compared with DPl; ${ }^{*} P<0 \cdot 05,{ }^{*} P<0 \cdot 01,{ }^{* *} P<0 \cdot 001$ compared with DP (Mann-Whitney $U$-tests at day 15 , one-way ANOVA at days 18 and 21$)$. Values are means \pm S.E.M. (d) Maternal serum oestradiol at days 7, 15, 18 and 21 of gestation in CP $(\bullet, n=7,8,9,7)$, DP $(\boldsymbol{\square}, n=9,7,7,10)$ and DPI $(\boldsymbol{\Lambda}, n=8,8,7,5)$ rats. $+P<0 \cdot 05,++P<0 \cdot 01$ compared with DP; ${ }^{*} P<0 \cdot 05,{ }^{*} * P<0 \cdot 01$ compared with DPI (Mann-Whitney $U$-tests). Values are means \pm S.E.M. (e) Maternal serum IGF-I at days 7, 15, 18 and 21 of gestation in CP $(\bullet, n=9,9,8,8)$, DP $(\mathbf{\square}, n=11,11,11,12)$ and DPI $(\boldsymbol{\Delta}, n=6,8,7,6)$ rats. $+++P<0 \cdot 001$ compared with DP; ${ }^{*} P<0 \cdot 05,{ }^{*} P<0 \cdot 01$ compared with $\mathrm{CP}$ (Mann-Whitney $U$-tests). Values are means \pm S.E.M. 
of pregnancy ensue, and this may contribute to the reduced calcium of diabetic pregnant offspring.

\section{Gestational changes in maternal hormone concentrations}

$\mathbf{1 , 2 5}(\mathrm{OH})_{2} \mathrm{D}_{3}$ The observed increase in maternal plasma $1,25(\mathrm{OH})_{2} \mathrm{D}_{3}$ concentration over the last third of normal pregnancy confirms the findings of previous investigations in the rat (Halloran et al. 1979, Verhaeghe et al. 1988b, Paulson et al. 1990). As the expression of both renal calbindins has previously been shown to be vitamin-Ddependent (Thomasset et al. 1982), this increase is likely to stimulate gene expression and may account for the increase in calbindin-D mRNA levels in the kidney that we have demonstrated here. It is difficult, however, to reconcile the severely reduced $1,25(\mathrm{OH})_{2} \mathrm{D}_{3}$ concentration seen in late gestation in our DP rats from day 15 and also reported by others at term (Demignon \& Bonneton-Rebut 1988, Mimouni et al. 1988, Verhaeghe et al. 1999) with the very high renal calbindin-D mRNA levels seen in the same group at the same time.

In contrast to the findings in kidney, the gestational profiles for placental calbindin- $\mathrm{D}_{9 \mathrm{~K}}$ and $1,25(\mathrm{OH})_{2} \mathrm{D}_{3}$ concentration did mirror each other for each of our experimental groups. However, despite the $1,25(\mathrm{OH})_{2} \mathrm{D}_{3}-$ responsive element in the calbindin- $\mathrm{D}_{9 \mathrm{~K}}$ gene (Darwish \& DeLuca 1992), placental calbindin- $\mathrm{D}_{9 \mathrm{~K}}$ expression is not dependent on this hormone (Glazier et al. 1995). It seems likely, therefore, that factors other than vitamin $\mathrm{D}_{3}$ metabolites are involved in activating the renal and placental calbindin genes in diabetic pregnancy.

PTH Several studies have reported an increase in PTH concentrations during the last few days of gestation in the rat (e.g. Bourdeau et al. 1990), consistent with the data reported here. One study has reported lower PTH concentrations in DP than in CP rats (Verhaeghe et al. 1999). However, clinical studies have found similar (Cruickshank et al. 1980, Mimouni et al. 1989) or reduced (Cruickshank et al. 1983) serum PTH concentrations in diabetic pregnant women compared with controls. In the non-pregnant diabetic rat, $\mathrm{PTH}$ concentrations have been found to be slightly lower than those in controls (Takeshita et al. 1994), which agrees with the early gestational measures in our study. However, no significant differences existed between the three groups over days 18 and 21. Although PTH has been shown to increase cytosolic concentration of renal calbindin- $\mathrm{D}_{28 \mathrm{~K}}$ in vivo (Hemmingsen et al. 1996), the PTH profile for our diabetic rats throughout gestation does not concur with that for the calbindins. It seems unlikely, therefore, that PTH is responsible for the altered calbindin-D mRNA expression patterns seen in placenta and kidney of diabetic pregnant animals.

PTHrP It is well documented that PTHrP acts mainly as an autocrine factor in the adult (Philbrick et al. 1996). In the fetal sheep, it has been shown to act on the placenta to regulate calcium transport (Rodda et al. 1988). Although this does not appear to happen in the rat (Shaw et al. 1991), absence of the PTHrP receptor in the mouse diminishes calcium acquisition by the fetus (Kovacs et al. 1996). The similarity between our PTHrP data and the placental calbindin- $\mathrm{D}_{9 \mathrm{~K}}$ mRNA towards term (significantly lower in DP rats, compared with increasing concentrations in $\mathrm{CP}$ rats) suggests that $\mathrm{PTHrP}$ might thus be a regulatory factor for placental calbindin- $\mathrm{D}_{9 \mathrm{~K}}$ mRNA. PTHrP has been shown to increase renal calbindin- $\mathrm{D}_{28 \mathrm{~K}}$ in the rat by a direct effect (Hemmingsen et al. 1996), but the changing pattern of maternal PTHrP seen in the CP and DP rats in this study did not parallel the renal calbindin-D profile for the two groups.

Calcitonin The lack of differences in calcitonin concentrations between our three groups throughout gestation compares well with previous human data for calcitonin (Cruickshank et al. 1980, 1983). Thus it seems unlikely that calcitonin affects calbindin-D expression in the placenta or kidney.

Oestradiol In the DP rats, oestradiol concentrations were lower than those in controls until day 21 , and failed to show the sharp peak found at day 18 in the CP group; this peak was also absent in the DPI group. Several previous studies have reported a similar peak in maternal oestradiol concentrations at or around day 18 of normal rat pregnancy (e.g. Garland et al. 1987). As the calbindin- $\mathrm{D}_{9 \mathrm{~K}}$ gene is known to have an oestrogen-responsive element (Darwish et al. 1991), it is tempting to speculate that there might be a causal link between this oestradiol peak and the coincident marked gestational increase in placental expression of calbindin- $\mathrm{D}_{9 \mathrm{~K}} \mathrm{mRNA}$ in the $\mathrm{CP}$ group. This proposal is supported by the blunted increase in placental calbindin- $\mathrm{D}_{9 \mathrm{~K}}$ mRNA expression and the absence of a peak in oestradiol in the diabetic pregnant rats. The lack of increase in oestradiol in the DPI group with a concurrent increase in calbindin- $\mathrm{D}_{9 \mathrm{~K}} \mathrm{mRNA}$ expression is, however, not consistent with this hypothesis.

Nevertheless, oestradiol concentrations were lower in the diabetic pregnant group than in either the insulintreated diabetic or control groups. Thus, if oestradiol does have a role in activating the placental calbindin- $\mathrm{D}_{9 \mathrm{~K}}$ gene, these reduced oestradiol concentrations may be the key to explaining the lower placental calbindin- $\mathrm{D}_{9 \mathrm{~K}} \mathrm{mRNA}$ of diabetic rats seen in our study. Oestradiol is apparently involved in control of the uterine calbindin- $\mathrm{D}_{9 \mathrm{~K}}$ gene (L'Horset et al. 1990), and uterine calbindin- $\mathrm{D}_{9 \mathrm{~K}}$ mRNA changes profoundly throughout pregnancy and lactation in the rat (Krisinger et al. 1992). Oestrogen can also inhibit uterine calbindin- $\mathrm{D}_{28 \mathrm{~K}}$ in the mouse (Opperman et al. 1992), perhaps explaining the greater renal calbindin mRNA levels in the DP rats in the face of lower oestradiol concentrations. 
IGF-I The sharp decline in maternal serum IGF-I concentrations from approximately half-way through normal pregnancy is in accordance with earlier observations in the rat (e.g. Gargosky et al. 1990). Reduced serum IGF-I concentrations in diabetic pregnancy, as here in the rat, have previously been reported in humans (Whittaker et al. 1990) and rabbits (D'Ercole et al. 1984). As the gestational profiles for IGF-I and calbindin-D mRNA levels were so dissimilar, it seems unlikely that IGF-I contributes to the altered calbindin-D mRNA expression of DP rats.

\section{Calbindin $m R N A$ expression, diabetes and hormonal control}

This study underscores the likely importance of interplay between regulatory factors of gene expression for calbindin- $\mathrm{D}_{28 \mathrm{~K}}$ and calbindin- $\mathrm{D}_{9 \mathrm{~K}}$ in the kidney and placenta in response to maternal diabetes. Our data pinpoint gestational day 18 as a likely time of control of calbindin-D expression in both kidney and placenta, and its alteration in diabetes. The current study, with previous work, points to an effect of diabetic pregnancy on oestradiol and PTHrP concentrations as being key to the altered renal and placental expression of calbindin mRNA and, thus, the derangement in calcium handling by these organs in this condition.

\section{Acknowledgements}

The calbindin- $\mathrm{D}_{28 \mathrm{~K}}$ probe was generously donated by $\mathrm{Dr}$ M Thomasset, Institut National de la Santé et de la Recherche Médicale, Paris, France. We thank Dr David Owen and Dr Ian Lang for performing one of the oestradiol assays, and Dr Val Hillier for clear statistical advice. The authors acknowledge the support of the Sir Jules Thorn Charitable Trust.

\section{References}

Anwana AB 1989 Renal function in the streptozotocin-diabetic rat. PhD Thesis. University of Manchester.

Benitez-Verguizes J \& Esbrit P 1994 Proliferative effect of parathyroid hormone-related protein on the hypercalcemic Walker 256 carcinoma cell line. Biochemical and Biophysical Research Communications 198 1281-1289.

Birdsey TJ, Husain SM, Garland HO \& Sibley CP 1995 The effect of diabetes mellitus on urinary calcium excretion in pregnant rats and their offspring. Journal of Endocrinology 145 11-18.

Bourdeau A, Manganella G, Thil-Trubert CL, Sachs C \& Cournot G 1990 Bioactive parathyroid hormone in pregnant rats and fetuses. American Journal of Physiology 258 E549-E554.

Comar CL 1956 Radiocalcium studies in pregnancy. Annals of the New York Academy of Sciences 64 281-298.

Cruickshank DP, Pitkin RM, Reynolds WA, Williams GA \& Hargis GK 1980 Altered calcium homeostasis in diabetic pregnancy. Journal of Clinical Endocrinology 50 264-267.

Cruickshank DP, Pitkin RM, Varner MW, Williams GA \& Hargis GK 1983 Calcium metabolism in diabetic mother, fetus and newborn infant. American Journal of Obstetrics and Gynecology 145 1010-1016.
Darwish H, Krisinger J, Furlow JD, Smith C, Murdoch FE \& DeLuca HF 1991 An estrogen-responsive element mediates the transcriptional regulation of calbindin-D9K gene in rat uterus. Journal of Biological Chemistry 266 551-558.

Darwish HM \& DeLuca HF 1992 Identification of a 1,25dihydroxyvitamin D3-responsive element in the $5^{\prime}$-flanking region of the rat calbindin- $\mathrm{D}_{9 \mathrm{~K}}$ gene. Proceedings of the National Academy of Sciences of the USA 89 603-607.

Demignon J \& Bonneton-Rebut C 1988 Effects of experimental diabetes on the vitamin $\mathrm{D}$ metabolism of pregnant rats and their fetuses. Calcified Tissue International 42 127-135.

D’Ercole AJ, Bose CL, Underwood LE \& Lawson EE 1984 Serum somatomedin-C concentrations in a rabbit model of diabetic pregnancy. Diabetes 33 590-595.

Fraser WD, Durham BH, Berry JL \& Mawer EB 1997 Measurement of plasma 1,25-dihydroxyvitamin D using a novel immunoextraction technique and immunoassay with iodine labelled vitamin $\mathrm{D}$ tracer. Annals of Clinical Biochemistry 34 632-637.

Gargosky SE, Walton PE, Owens PC, Wallace JC \& Ballard FJ 1990 Insulin-like growth factor-I (IGF-I) and IGF-binding proteins both decline in the rat during late pregnancy. Journal of Endocrinology 127 383-390.

Garland HO, Atherton JC, Baylis C, Morgan MRA \& Milne CM 1987 Hormone profiles for progesterone, oestradiol, prolactin, plasma renin activity, aldosterone and corticosterone during pregnancy and pseudopregnancy in two strains of rat: correlation with renal studies. Journal of Endocrinology 113 435-444.

Garland HO, Forshaw AG \& Sibley CP 1997 Dietary essential fatty acid supplementation, urinary calcium excretion and reproductive performance in the diabetic pregnant rat. Journal of Endocrinology $153357-363$.

Gill RK \& Christakos S 1995 Regulation by estrogen through the $5^{\prime}$-flanking region of the mouse calbindin-D28K gene. Molecular Endocrinology 9 319-326.

Glazier JD, Atkinson DE, Thornburg KL, Sharpe PY, Edwards D, Boyd RDH \& Sibley CP 1992 Gestational changes in $\mathrm{Ca}^{2+}$ transport across rat placenta and mRNA for calbindin ${ }_{9 K}$ and $\mathrm{Ca}^{2+}$-ATPase. American Journal of Physiology 263 R930-R935.

Glazier JD, Mawer EB \& Sibley CP 1995 Calbindin-D9K gene expression in rat chorioallantoic placenta is not regulated by 1,25-dihydroxyvitamin $\mathrm{D}_{3}$. Pediatric Research 37 720-725.

Green R \& Hatton TM 1988 Calcium handling by the kidney during pregnancy in the anaesthetised rat. Journal of Physiology $40317 \mathrm{P}$.

Halloran BP, Barthell EN \& DeLuca HF 1979 Vitamin D metabolism during pregnancy and lactation in the rat. Proceedings of the National Academy of Sciences of the USA 76 5549-5553.

Hemmingsen C, Staun M, Lewin E, Nielsen PK \& Olgaard K 1996 Effect of parathyroid hormone on renal calbindin- $\mathrm{D}_{28 \mathrm{~K}}$. Journal of Bone and Mineral Research 11 1086-1093.

Huang YC \& Christakos S 1988 Modulation of rat calbindin- $\mathrm{D}_{28}$ gene expression by 1,25 -dihydroxyvitamin $\mathrm{D}_{3}$ and dietary alteration. Molecular Endocrinology 2 928-935.

Huang Y, Lee S, Stolz R, Gabrielides C, Pansini-Porta A, Bruns ME, Bruns DE, Miffin TE, Pike JW \& Christakos S 1989 Effect of hormones and development on the expression of the rat 1,25dihydroxyvitamin $\mathrm{D}_{3}$ receptor gene. Journal of Biological Chemistry 264 17454-17461.

Husain SM, Birdsey TJ, Glazier JD, Mughal MZ, Garland HO \& Sibley CP 1994 Effect of diabetes mellitus on maternofetal flux of calcium and magnesium and calbindin- $\mathrm{D}_{9 \mathrm{~K}}$ mRNA expression in rat placenta. Pediatric Research 35 376-381.

Kalu DN, Masoro EJ, Yu BP, Hardin RR \& Hollis BW 1988 Modulation of age-related hyperparathyroidism and senile bone loss in Fischer rats by soy protein and food restriction. Endocrinology 122 1847-1854.

Kovacs CS, Lanske B, Hunzelman JL, Guo J, Karaplis AC \& Kronenberg HM 1996 Parathyroid hormone-related peptide 
(PTHrP) regulates fetal-placental calcium transport through a receptor distinct from the $\mathrm{PTH} / \mathrm{PTHrP}$ receptor. Proceedings of the National Academy of Sciences of the USA 15233-15238.

Krisinger J, Dann JL, Jeung EB \& Leung PC 1992 Calbindin- $\mathrm{D}_{9 \mathrm{~K}}$ gene expression during pregnancy and lactation in the rat. Molecular and Cellular Endocrinology 88 119-128.

Lapillone A, Guerin S, Braillon P, Claris O, Delmas PD \& Salle BL 1997 Diabetes during pregnancy does not alter whole body bone mineral content in infants. Journal of Clinical Endocrinology and Metabolism 82 3993-3997.

L'Horset F, Perret C, Brehier A \& Thomasset M 199017 Betaestradiol stimulates the calbindin-D9K (CaBP9K) gene expression at the transcriptional and posttranscriptional levels in the rat uterus. Endocrinology 127 2891-2897.

Li H \& Christakos S 1991 Differential regulation by 1,25-dihydroxyvitamin $\mathrm{D}_{3}$ of calbindin- $\mathrm{D}_{9 \mathrm{~K}}$ and calbindin- $\mathrm{D}_{28 \mathrm{~K}}$ gene expression in mouse kidney. Endocrinology 128 2844-2852.

Lomri N, Perret C, Gouhier N \& Thomasset M 1989 Cloning and analysis of calbindin- $\mathrm{D}_{28 \mathrm{~K}} \mathrm{cDNA}$ and its expression in the central nervous system. Gene $\mathbf{8 0} 87-98$.

Miller SC, Shupe JG, Redd EH, Miller MA \& Omura TH 1986 Changes in bone mineral and bone formation rates during pregnancy and lactation in rats. Bone 7 283-287.

Mimouni F, Tsang RC, Hertzberg VS \& Miodovnik M 1986 Polycythemia, hypomagnesemia, and hypocalcemia in infants of diabetic mothers. American Journal of Diseases of Childhood $\mathbf{1 4 0}$ 798-800.

Mimouni F, Steichen JJ, Tsang RC, Hertzberg V \& Miodovnik M 1988 Decreased bone mineral content in infants of diabetic mothers. American Journal of Perinatology 5 339-343.

Mimouni F, Tsang RC, Hertzberg VS, Neumann V \& Ellis K 1989 Parathyroid hormone and calcitriol changes in normal and insulindependent diabetic pregnancies. Obstetrics and Gynecology 74 49-54.

Mimouni F, Loughead JL, Tsang RC \& Khoury J 1990 Postnatal surge in serum calcitonin concentrations: no contribution to neonatal hypocalcemia in infants of diabetic mothers. Pediatric Research 28 493-495.

Naranjo A, Loarte D, de Miguel F \& Esbrit P 1994 Plasma parathormone-related protein and alkaline and tartrate-resistant acid phosphatases during the development of hypercalcaemia in Walker 256 tumour-bearing rats. Medical Science Research 22 345-346.

Opperman LA, Saunders TJ, Bruns DE, Boyd JC, Mills SE \& Bruns ME 1992 Estrogen inhibits calbindin- $\mathrm{D}_{28 \mathrm{~K}}$ expression in mouse uterus. Endocrinology 310 1728-1735.

Paulson SK, Ford KK \& Langman CB 1990 Pregnancy does not alter the metabolic clearance of 1,25-dihydroxyvitamin D in rats. American Journal of Physiology 258 E158-E162.

Philbrick WM, Wysolmerskin JJ, Galbraith S, Holt E, Orloff JJ, Yang KH, Vasavada RC, Weir EC, Broadus AE \& Stewart AF 1996 Defining the roles of parathyroid hormone-related protein in normal physiology. Physiology Reviews 76 127-173.
Rodda CP, Kubota M, Heath JA, Ebeling PR, Moseley JM, Care AD, Caple IW \& Martin TJ 1988 Evidence for a novel parathyroid hormone-related protein in fetal lamb parathyroid glands and sheep placenta: comparisons with a similar protein implicated in humoral hypercalcaemia of malignancy. Journal of Endocrinology 117 261-271.

Shareghi GR \& Stoner LC 1978 Calcium transport across segments of the rabbit distal nephron in vitro. American Journal of Physiology 235 F367-F375.

Shaw AJ, Mughal MZ, Maresh MJA \& Sibley CP 1991 Effects of two synthetic parathyroid hormone-related protein fragments on maternofetal transfer of calcium and magnesium and release of cyclic AMP by the in vivo perfused rat placenta. Journal of Endocrinology 129 399-404.

Štulc J \& Štulcová B 1986 Transport of calcium by the placenta of the rat. Journal of Physiology 371 1-16.

Takeshita N, Yoshino Y, Mutoh S \& Yamaguchi I 1994 Possible involvement of vitamin- $\mathrm{D}_{3}$ deficiency and relatively enhanced bone resorption in the development of bone loss in streptozotocininduced diabetic rats. Life Science 55 291-299.

Thomasset M, Parkes CO \& Cuisinier-Gleizes P 1982 Rat calciumbinding proteins: distribution, development, and vitamin D dependence. American Journal of Physiology 243 E483-E488.

Tsang RC, Kleinman LI, Sutherland JM \& Light IJ 1972 Hypocalcemia in infants of diabetic mothers. Studies in calcium, phosphorus and magnesium metabolism and parathormone responsiveness. Journal of Pediatrics 80 384-395.

Uriu-Hare JY, Stern JS, Reaven GM \& Keen CL 1985 The effect of maternal diabetes on trace element status and fetal development in the rat. Diabetes 34 1031-1040.

Verhaeghe J, Bouillon R, Lissens W, Visser WJ \& Van Assche FA 1988 a Diabetes and low Ca-P diet have opposite effects on adult and fetal bone mineral metabolism. American Journal of Physiology 254 E496-E504.

Verhaeghe J, Thomasset M, Brehier A, Van Assche FA \& Bouillon R $1988 b 1,25(\mathrm{OH})_{2} \mathrm{D}_{3}$ and Ca-binding protein in fetal rats: relationship to the maternal vitamin D status. American Journal of Physiology 254 E505-E512.

Verhaeghe J, Van Bree R, Van Herck E, Rummens K, Vercruysse L, Bouillon R \& Pijnenborg R 1999 Pathogenesis of fetal hypomineralization in diabetic rats: evidence for delayed bone maturation. Pediatric Research 45 209-217.

Whittaker PG, Stewart MO, Taylor A, Howell RJS \& Lind TL 1990 Insulin-like growth factor I and its binding protein I during normal and diabetic pregnancies. Obstetrics and Gynecology 76 223-229.

Received 2 March 1999

Revised manuscript received 29 July 1999

Accepted 21 August 1999 